russkaia revoliutsiia: Vosstanie v Petrograde, was published; in 1971 the second volume, Vtoraia russkaia revoliutsiia: Moskva, front, periferiia, came out. The publication of volume 1 shows the extent to which Soviet historiography had gradually come to accept Burdzhalov's scholarship on the February Revolution, as well as the extent to which the author had support, not only among prominent historians, but also within the party leadership. The Stalin question was a burning one during the first years of Brezhnev's rule, and it was a fortunate time for Burdzhalov's book to appear. We cannot rule out the possibility that it would not have been published even a year or so later.

Developing ideas explored in his 1956 articles, Burdzhalov showed that the Bolsheviks did not direct the February Revolution, which was largely a spontaneous affair, but instead were drawn into the movement by the tide of events. Internally divided and taken by surprise, the Bolshevik party was unable to assume leadership of the revolution, created by workers and supported by the local garrison. The Bolsheviks, Burdzhalov argued, cooperated closely with the Mensheviks and SRs, who also endeavored to overthrow the autocracy. He even treated Trotsky and Martov in an unusually fresh manner.

Following publication of his work on the February Revolution, Burdzhalov continued to investigate the revolutionary events of 1917 , in the hope of writing a book on the party during the April crisis. Before completing this research, he was stricken by Parkinson's disease. After ten years of determined struggle against the illness, he died in Moscow on 31 December 1985.

Burdzhalov was a complex man, hard-working, intense, modest, honest, generous, witty. He had a powerful presence, which contrasted with his slight frame and size. Eduard Nikolaevich will be missed by family and friends, some of whom disagreed with his stance after 1953 , others of whom discreetly approved his behavior because he was courageous enough to pursue his own, and their own, inner promptings.

Donald J. Raleigh University of Hawaii

\title{
TATJANA CIZEVSKA, 1924-1986
}

Tatjana Cizevska, formerly of the University of Illinois and more recently professor of Slavic languages and literatures at Wayne State University in Detroit, died 23 February 1986. She had been ill with cancer for several years. She was born in Paris, France, on 18 June 1924. Her father was the noted Slavic scholar Dmitrii Ivanovich Chezhevskii. Her mother was the late Dr. Lydia Marshak, who practiced dermatology in Chicago for many years. Cizevska's immediate survivor is her maternal aunt Frances Sobotka, who inaugurated the teaching of Russian at the University of Illinois after World War II.

Cizevska had elementary and secondary schooling in Czechoslovakia, Austria, England, and the United States. She came to this country in 1940 and became a citizen in 1946, having meanwhile earned a BA at the University of Chicago, studying history and Greek. In 1949 she earned the MA from Columbia and in 1955 the PhD from HarvardRadcliffe, both in Slavic languages and literatures. She was primarily a linguist by training, and her principal scholarly interest was Old Russian letters. Her dissertation advisor was Roman Jakobson.

She worked briefly at Syracuse, Georgetown, Washington, Michigan, and Michigan State universities, as well as at the Human Relations Area Files in New Haven, before going to the University of Illinois. She taught there from 1958 to 1965 . In 1965 she moved to Wayne State University, where she taught in the Slavic Department and, in the years immediately preceding her death, part-time in classics.

While at Illinois she received in 1960-1961 a grant from the IUCTG for research in the USSR. She also edited the AAASS Newsletter from 1963 to 1966. At Wayne State 
she was an active member of the editorial board of the WSU Press. Her scholarly publications include Glossary of the Igor' Tale, as well as a translation of her father's study of Evgenii Onegin.

She was a cherished friend of many Slavists in the United States, and they will certainly remember her warmly for years to come.

\author{
KenNeTH N. BRostrom \\ Wayne State University \\ RALPH T. FISHER \\ University of Illinois, Urbana-Champaign
}

\title{
JAROSLAV ŠIDAK, 1903-1986
}

Jaroslav Šidak, professor emeritus of history at the University of Zagreb, died on 25 March 1986 under most grievous circumstances. With his passing Croatian historiography lost its most outstanding practitioner of the past four decades.

Born into a Czech family in Vienna, Jaroslav Šidak was brought up in Zagreb and completed all of his schooling there. He earned his doctoral degree in history with a thesis on "Problem bosanske crkve u našoj historiografiji od Petranovića do Glušca" (1935). After a brief period as a gymnasium instructor at Senj and Zagreb and work in the editorial board of Hrvatska enciklopedija, he was appointed an assistant professor of Croatian history at the University of Zagreb (1943), where he continued as an associate (1945) and full professor (1954) of modern European history. He held the chair of Croatian history from 1958 to his retirement in 1973.

Sidak was one of those rare historians who was utterly untouched by the conventions of specialization in historiography's various chambers-old and new. But unlike the generalists of earlier times he approached every field of inquiry with the command of a specialist. His research, consisting of over two hundred studies and articles, spanned the centuries of Croatian and south Slavic history from the reign of Demetrius Zvonimir to the intellectual maturation of Stjepan Radić. Quite obviously, this breadth was purchased by his absolute control of the sources and literature, something that made him impervious to every sort of self-important theories, mannerisms, and fads.

Šidak's work was dominated by four topics, each a combination of intellectual and political approaches to history. His earliest area of interest was medieval Bosnian neoManichaeism, whose mysteries he saw quite differently in various stages of his progress toward unmatched authority in this field. In his original conception (1935), Sidak saw the Church of Bosnia as an independent-but nonheretical-church organization derived from the Catholic diocese of Bosnia. This congregation was an expressly monastic church, continued many aspects of religious life derived from the Cyrillo-Methodian tradition, and separated itself from Rome in the 1230s in reaction to papal attempts to make it conform to Latin ecclesiastical and liturgical practices. In 1954, after much rethinking and after the publication of several new sources, Šidak increasingly accepted the classical thesis of Franjo Rački, whereby the Church of Bosnia was by provenance a neo-Manichean sect. Nevertheless, he continued to advance many convincing counter-proofs against supposed Bosnian dualist beliefs, convinced that the character of Bosnian doctrines was still far from clear.

Three other topics competed for Šidak's attention during the last four decades of his scholarly life. He was, first, the foremost twentieth century student of baroque Slavism among the Croats, his studies of Juraj Križanić and Pavao Ritter Vitezović being the great synthetic statements on the subjects. Second, Šidak was the greatest specialist in the history of Croatian revival and the Illyrianist movement, his distinction between cultural Illyrianism and political Croatism having ended many caprices of imagination 